\title{
Analisis faktor risiko demografi dan dukungan sosial suami terhadap kejadian postpartum blues di RSUD Dr. Dradjat Prawiranegara Kabupaten Serang
}

\author{
Qonita $^{1^{*}}$, Umalihayati $^{2}$ \\ 1,2 Politeknik Kesehatan 'Aisyiyah Banten
}

\section{INFORMASI ARTIKEL:}

\section{Riwayat Artikel:}

Tanggal diterima, 19 Agustus 2021

Tanggal direvisi, 26 November 2021

Tanggal dipublikasi, 5 Desember 2021

Kata kunci:

Postpartum blues;

Faktor Demografi;

Dukungan Sosial;

10.32536/jrki.v5i2.190
Keyword:

Postpartum blue; Demografi Factors; Sosial support;

\begin{abstract}
ABSTRAK
Latar belakang: Dalam masa nifas, ibu postpartum akan mengalami adaptasi fisiologis, psikologis dan adaptasi sosial. Namun, tidak semua ibu postpartum bisa melewati adaptasi masa nifas dengan lancar. Ibu postpartum bisa saja mengalami gangguan psikologis masa nifas salah satunya kecemasan. Dari setiap 1000 wanita hamil, sekitar $17 \%$ wanita akan mengunjungi unit kejiwaan. Postpartum blues terjadi pada sekitar $50 \%$ wanita dalam waktu 4-5 hari setelah melahirkan. Tujuan penelitian: Menganalisis faktor risiko demografi dan dukungan sosial suami terhadap kejadian postpartum blues. Metode : Desain penelitian yang di gunakan adalah jenis penelitian analitik dengan pendekatan cross sectional. Jumlah sampel yaitu 300 ibu nifas yang diambil secara accidental sampling. Data yang digunakan adalah data primer. Instrumen penelitian menggunakan kuesioner yang berisi untuk mengkaji faktor risiko dan pengukuran postpartum blues (skala EPDS). Data dianalisis dengan menggunakan uji chi-square dengan tingkat kesalahan $(a=0,05)$. Hasil: Masih terdapat ibu nifas yang mengalami Postpartum blues sebanyak 112 orang (37,3\%). Faktor-faktor yang terbukti merupakan faktor risiko terjadinya postpartum blues yaitu usia (OR=2,062; 95\% Cl: 1,090-3,903), status ekonomi (OR=3,559; 95\% Cl: 1,964-6,448) dan dukungan sosial suami (OR=6,389; 95\% $\mathrm{Cl}: 2,905-14,050)$. Simpulan: Dukungan sosial suami merupakan faktor risiko yang paling dominan berkontribusi terhadap terjadinya postpartum blues.
\end{abstract}

Background: During the postpartum period, the postpartum mothers will experience physiological, psychological and social adaptations. However, not all postpartum mothers can pass the postpartum adaptation smoothly. Postpartum mothers may experience psychological disorders during the postpartum period, one of which is anxiety. Out of every 1000 pregnant women, about $17 \%$ of women will visit a psychiatric unit. Postpartum blues occur in about 50\% of women within 4-5 days after delivery. Research objectives: To analyze the demographic risk factors and husband's social support for the incidence of postpartum blues. Methods: The research design used was an analytical research type with a cross sectional approach. The number of samples was 300 postpartum mothers taken by accidental sampling. The data used was primary data. The research instrument used a questionnaire containing risk factors assessment and measurement of postpartum blues (EPDS scale). The data was analyzed using chi-square test with an error rate (a $=0.05)$. Results: There are still 112 postpartum mothers who experience Postpartum Blues by the amount of $37.3 \%$. The factors that proved in postpartum blues risk factors were age factor (OR=2,062; 95\% Cl: 1,090-3.903), economic status (OR=3,559; 95\% Cl: 1,964-6,448) and husband's social support (OR=6,389; 95\% Cl: 2.905-14.050). Conclusion: Husband's social support is the most dominant risk factor in contributing the occurrence of postpartum blues. 


\section{Pendahuluan}

Persalinan yang berlangsung lancar sangat membahagiakan bagi setiap ibu. Persalinan merupakan salah satu anugerah terindah dari Allah SWT yang diberikan kepada kaum wanita. Setelah menjalani masa kehamilan selama 9 bulan, bukan waktu yang singkat, tentunya banyak hal-hal yang dialami oleh seorang ibu baik itu perubahan fisik maupun perubahan psikologis sehingga membutuhkan adaptasi (Salmah, 2018).

Perubahan psikologik pada ibu nifas dimanifestasikan dalam bentuk emosi yang labil, sedih dan mudah tersinggung. Apabila hal ini berlanjut bisa menjadi dasar terjadinya kelainan psikologik pada ibu nifas (Chuningham, dkk, 2012). Selain itu kelelahan yang terjadi pada awal masa nifas, kurang tidur, perasaan tidak mampu merawat bayi dengan baik, masalah citra tubuh dan proses adaptasi hormonal juga menjadi faktor terjadinya postpartum blues (Kerstin UM dan Prime DK, 2013).

Perubahan yang mendadak pada ibu postpartum penyebab utamanya adalah kekecewaan emosional, rasa sakit pada masa nifas awal, kelelahan karena kurang tidur selama persalinan dan kecemasan pada kemampuannya untuk merawat bayinya, rasa takut tidak menarik lagi bagi suaminya, terutama emosi selama minggu pertama menjadi labil dan perubahan suasana hatinya dalam 3 - 4 hari pertama, masa ini sangat bervariasi dan dipengaruhi oleh begitu banyak faktor, maka penekanan utama adalah pendekatan keperawatan dengan memberikan bantuan, simpati dan dorongan semangat (Kirana, 2015).

Dari setiap 1000 wanita hamil, sekitar 17\% wanita akan mengunjungi unit kejiwaan. Lima persen akan mengalami gangguan mood depresi yang ringan pada minggu pertama setelah melahirkan yaitu postpartum blues dan $2 \%$ akan berkembang menjadi psikosis pada masa nifas. Antara 10 sampai $15 \%$ akan berkembang menjadi depresi setelah melahirkan. Postpartum blues terjadi pada sekitar 50\% wanita dalam waktu 4-5 hari setelah melahirkan (Salmah, 2018).

Angka kejadian postpartum blues di seluruh dunia cukup tinggi yakni $26-85 \%$. Data tersebut menunjukkan $81 \%$ angka kematian ibu (AKI) akibat

\footnotetext{
* Korespondensi penulis.

Alamat E-mail: qonita@poltekkes-aisyiyahbanten.ac.id
}

komplikasi selama hamil dan bersalin, dan 25\% kasus postpartum blues (Salmah, 2018). Angka kejadian postpartum blues di Indonesia berkisar antara $50-70 \%$ pada ibu post partum (Desfanita et al, 2015). Postpartum blues dialami oleh ibu postpartum yang bersifat sementara dan terjadi pada minggu pertama setelah kelahiran. Postpartum depression dialami oleh $34 \%$ ibu postpartum dan $1 \%$ yang mengalami postpartum psikosis (Yodatama, C, et .al, 2015).

Faktor-faktor yang menyebabkan postpartum blues diantaranya faktor dukungan keluarga, pengetahuan, status kehamilan, jenis persalinan, faktor hormonal (berupa perubahan kadar estrogen, progesteron, prolaktin dan estriol yang terlalu rendah. Kadar estrogen turun secara bermakna setelah melahirkan, ternyata estrogen memiliki efek supresi aktifitas enzim nonadreanalin maupun serotin yang berperan dalam suasana hati dan kejadian depresi), faktor demografik (paritas dan usia), pekerjaan, latar belakang ibu postpartum, faktor fisik, ketidakmampuan beradaptasi, pengalaman dalam proses kehamilan dan persalinan (Qiftiyah, M, 2018).

Kurangnya dukungan sosial keluarga atau suami akan berdampak ke keadaan psikis ibu yang tengah mengalami postpartum blues. Ketidaktahuan ibu postpartum dan keluarga tentang postpartum blues juga akan berdampak pada kondisi ibu postpartum yang mengalami gejala postpartum blues. Jika kondisi postpartum blues tidak disikapi dengan benar, bisa berdampak pada hubungan ibu dengan bayinya, bahkan anggota keluarga yang lain juga bisa merasakan dampak dari postpartum blues tersebut. Jika postpartum blues dibiarkan, dapat berlanjut menjadi depresi pasca melahirkan, yaitu berlangsung lebih dan hari ke-7 pasca persalinan. Depresi setelah melahirkan rata-rata berlangsung tiga sampai enam bulan, bahkan terkadang sampai delapan bulan. Pada keadaan lanjut dapat mengancam keselamatan diri dan anaknya (Qiftiyah, M, 2018).

Penelitian ini bertujuan untuk mengetahui gambaran kejadian postpartum blues, menganalisis faktor risiko demografi dan dukungan sosial suami terhadap kejadian postpartum blues, dan faktor dominan yang mempengaruhi kejadian postpartum blues di RSUD Dr. Dradjat Prawiranegara Kabupaten Serang. 


\section{Metode penelitian}

Desain penelitian yang di gunakan adalah jenis penelitian analitik dengan pendekatan cross sectional. Sedangkan metode penelitian yang digunakan adalah dengan menggunakan metode survei, yaitu sebuah desain penelitian yang memberikan uraian kuantitatif dari sejumlah populasi (sampel) melalui proses pengumpulan data dengan menggunakan kuesioner sebagai alat pengumpul datanya. Kemudian dilakukan pengujian hipotesis secara spesifik untuk mengetahui faktor dominan dan faktor risiko mana saja dari variabel independen yang berhubungan dengan postpartum blues.

Populasi Penelitian ini adalah seluruh ibu nifas di RSUD Dr. Dradjat Prawiranegara pada bulan Januari s.d Maret 2021 yang berjumlah 743 orang. Jumlah sampel yaitu 300 ibu nifas yang diambil secara accidental sampling.

Instrumen penelitian menggunakan kuesioner yang berisi untuk mengkaji faktor risiko dan pengukuran postpartum blues dengan menggunakan skala EPDS.

Data dianalisis dengan menggunakan uji chisquare dengan tingkat kemaknaan 95\% $(a=0,05)$, estimasi yang digunakan adalah OR dan $95 \% \mathrm{Cl}$. Analisis multivariate yang digunakan adalah Regresi Logistik Ganda.

\section{Hasil dan Pembahasan}

Hasil penelitian yang menunjukkan kejadian postpatum blues disajikan pada Tabel 1 .

Tabel 1. Distribusi Frekuensi Postpartum blues di RSUD Dr. Dradjat Prawiranegara Kabupaten Serang

\begin{tabular}{lcc}
\hline Postpartum blues & F & $\%$ \\
\hline Ya & 112 & 37,3 \\
Tidak & 188 & 62,7 \\
Total & 300 & 100 \\
\hline
\end{tabular}

Berdasarkan tabel 1. dapat diketahui bahwa masih terdapat ibu nifas yang mengalami postpartum blues sebanyak 112 orang $(37,3 \%)$ di RSUD Dr. Dradjat Prawiranegara Kabupaten Serang.
Postpartum blues adalah suatu sindroma gangguan afek ringan yang sering tampak dalam minggu pertama setelah persalinan dan memuncak pada hari ke tiga sampai kelima dan menyerang dalam rentang waktu 14 hari terhitung setelah persalinan (Rini, S, 2016).

Dari setiap 1000 wanita hamil, sekitar $17 \%$ wanita akan mengunjungi unit kejiwaan. Lima persen akan mengalami gangguan mood depresi yang ringan pada minggu pertama setelah melahirkan yaitu postpartum blues dan $2 \%$ akan berkembang menjadi psikosis pada masa nifas. Antara 10 sampai $15 \%$ akan berkembang menjadi depresi setelah melahirkan. Postpartum blues terjadi pada sekitar $50 \%$ wanita dalam waktu 4-5 hari setelah melahirkan (Salmah, 2018).

Angka kejadian postpartum blues di seluruh dunia cukup tinggi yakni 26-85\%. Data tersebut menunjukkan $81 \%$ angka kematian ibu (AKI) akibat komplikasi selama hamil dan bersalin, dan $25 \%$ kasus postpartum blues. Angka kejadian postpartum blues di Indonesia berkisar antara 5070\% pada ibu postpartum. Postpartum blues dialami oleh ibu postpartum yang bersifat sementara dan terjadi pada minggu pertama setelah kelahiran. Postpartum depression dialami oleh $34 \%$ ibu postpartum dan $1 \%$ yang mengalami postpartum psikosis (Salmah, 2018; Desfanita et al, 2015; Yodatama et al, 2015). 
Tabel 2. Faktor Risiko Demografi dan Dukungan Sosial Suami Terhadap Kejadian Postpartum blues di RSUD Dr. Dradjat Prawiranegara Kabupaten Serang

\begin{tabular}{|c|c|c|c|c|c|c|c|c|}
\hline \multirow[t]{3}{*}{ Faktor Risiko } & \multicolumn{4}{|c|}{ Postpartum blues } & \multirow[t]{3}{*}{ Total } & \multirow[t]{3}{*}{$\%$} & \multirow{3}{*}{$\begin{array}{c}\text { OR } \\
(95 \% \mathrm{Cl})\end{array}$} & \multirow[t]{3}{*}{$p$-value } \\
\hline & \multicolumn{2}{|c|}{ Ya } & \multicolumn{2}{|c|}{ Tidak } & & & & \\
\hline & $\mathbf{F}$ & $\%$ & $\mathbf{F}$ & $\%$ & & & & \\
\hline \multicolumn{9}{|l|}{ Usia } \\
\hline Risiko Tinggi & 30 & 52,6 & 27 & 47,4 & 57 & 100 & 2,182 & 0,012 \\
\hline Risiko Rendah & 82 & 33,7 & 161 & 66,3 & 243 & 100 & $(1,217-3,912)$ & \\
\hline \multicolumn{9}{|l|}{ Pendidikan } \\
\hline Pendidikan Rendah & 40 & 41,2 & 57 & 58,8 & 97 & 100 & 1,277 & 0,402 \\
\hline Pendidikan Tinggi & 72 & 35,5 & 131 & 64,5 & 203 & 100 & $(0,777-2,097)$ & \\
\hline \multicolumn{9}{|l|}{ Paritas } \\
\hline Primipara & 40 & 31,7 & 86 & 68,3 & 126 & 100 & 0,659 & 0,114 \\
\hline Multipara & 72 & 41,4 & 102 & 58,6 & 174 & 100 & $(0,407-1,066)$ & \\
\hline \multicolumn{9}{|l|}{ Status Ekonomi } \\
\hline Rendah & 93 & 48,7 & 98 & 51,3 & 191 & 100 & 4,495 & 0,000 \\
\hline Tinggi & 19 & 17,4 & 90 & 82,6 & 109 & 100 & $(2,541-7,952)$ & \\
\hline \multicolumn{9}{|l|}{ Dukungan Sosial Suami } \\
\hline Kurang & 33 & 76,7 & 10 & 23,3 & 43 & 100 & 7,435 & \\
\hline Baik & 79 & 30,7 & 178 & 69,3 & 257 & 100 & $(3,493-15,827)$ & 0,000 \\
\hline
\end{tabular}

Analisis bivariate digunakan untuk menentukan variabel yang akan disertakan dalam model. Variabel yang menjadi kandidat model multivariate adalah variabel independen dengan nilai $\mathrm{p}<0,25$ dalam analisis bivariate. Variabelvariabel yang masuk ke dalam model multivariate yaitu usia ( $p$-value $=0,012<0,25)$, paritas ( $p$-value $=$ $0,114<0,25)$, status ekonomi $(p$-value $=0,000<0,25)$ dan dukungan suami ( $p$-value $=0,000<0,25)$.

Tabel 3. Model Akhir Hasil Analisis Regresi Logistik Ganda Faktor Risiko Demografi dan Dukungan Sosial Suami Terhadap Terjadinya Postpatum Blues

\begin{tabular}{lcc}
\hline \multirow{2}{*}{ Variabel } & Model I & Model II \\
\cline { 2 - 3 } \cline { 2 - 3 } Usia & OR (95\% Cl) & OR (95\% Cl) \\
\cline { 2 - 3 } Paritas & $2,159^{*}$ & $2,062^{*}$ \\
& $(1,135-4,107)$ & $(1,090-3,903)$ \\
Status Ekonomi & 0,603 & - \\
& $(0,352-1,035)$ & \\
Dukungan & $3,602^{*}$ & $3,559^{*}$ \\
Sosial Suami & $(1,980-6,554)$ & $(1,964-6,448)$ \\
$\mathrm{n}$ & $6,487^{*}$ & $6,389^{*}$ \\
$\mathrm{R}^{2}$ & $(2,935-14,338)$ & $(2,905-14,050)$ \\
\hline
\end{tabular}

Dilakukan analisis regresi logistik ganda dengan memasukkan satu persatu variabel independen ke dalam model, tetapi kemudian satu persatu variabel independen dikeluarkan dari model berdasarkan kriteria kemaknaan statistik tertentu. Variabel yang dapat masuk dalam model regresi logistik adalah variabel yang mempunyai nilai $p$-value $<0,05$.
Akhir model yang dihasilkan dari analisis multivariate (Model II) yaitu dapat diketahui variabel yang diduga dapat mempengaruhi terjadinya postpartum blues pada ibu nifas yaitu usia, status ekonomi dan dukungan sosial suami, sedangkan variabel yang paling dominan mempengaruhi terdapat pada variabel dukungan suami dimana hasil analisis multivariate didapatkan nilai OR 6,389 yang artinya ibu dengan dukungan sosial suami yang kurang mempunyai peluang 6,389 kali untuk terjadinya postpartum blues dibandingkan dengan ibu yang dukungan sosial suaminya baik. Masing-masing variabel dapat digunakan untuk memprediksi terjadinya postpartum blues sebesar $24,6 \%\left(R^{2} 0,246\right)$ dan sisanya dapat diprediksi oleh variabel lain.

\section{Usia Terhadap Terjadinya Postpartum blues}

Berdasarkan hasil analisis bivariate menunjukkan bahwa ibu nifas yang memiliki usia resiko tinggi lebih banyak pada ibu yang mengalami postpartum blues (52,6\%) dibandingkan dengan ibu yang memiliki usia resiko rendah $(33,7 \%)$, nilai $p$-value 0,012 yang berarti usia memiliki hubungan terhadap terjadinya postpartum blues. Sedangkan hasil multivariate menunjukkan bahwa $p$-value sebesar 0,026 ( $p$ value $<0,05)$ yang artinya usia merupakan faktor risiko terhadap terjadinya postpartum blues dan ibu nifas yang memiliki usia risiko tinggi memiliki peluang 2,062 kali untuk terjadinya postpartum blues dibandingkan dengan ibu yang memiliki usia resiko rendah (OR=2,062; 95\% Cl: 1,090-3,903). 
Hasil penelitian ini sesuai dengan hasil penelitian yang mengatakan bahwa usia ibu postpartum memiliki makna secara statistik karena memiliki nilai $p(0,047)<(0,05)$, sehingga didapatkan hubungan yang signifikan antara usia dengan kejadian baby blues syndrome. Nilai OR yang didapatkan pada variabel ini bernilai 4,000 , menunjukkan bahwa ibu postpartum yang berada pada usia berisiko (berusia $<20$ tahun dan $>35$ tahun) memiliki 4,000 kali kemungkinan menderita baby blues syndrome (Pramasatya, 2018).

Kejadian postpartum blues lebih banyak dialami oleh wanita yang berusia kurang dari 20 tahun atau lebih dari 35 tahun (81,8\%). Kehamilan dan persalinan pada remaja menjadi salah satu faktor pendukung terjadinya postpartum blues (Salmah, 2018).

\section{Pendidikan Terhadap Terjadinya Postpartum blues}

Berdasarkan hasil analisis bivariate dan multivariate menunjukkan bahwa ibu nifas yang memiliki pendidikan rendah lebih banyak pada ibu yang mengalami postpartum blues $(41,2 \%)$ dibandingkan dengan ibu yang memiliki pendidikan tinggi $(35,5 \%)$. Pendidikan dalam hasil analisis statistik menunjukkan $p$-value sebesar $0,402$ ( $p>0,05)$, yang artinya pendidikan tidak berhubungan terhadap terjadinya postpartum blues.

Hasil penelitian ini tidak sesuai dengan penelitian yang dilakukan oleh Fitriana, L.A., \& Nurbaeti, S (2016), menyatakan bahwa pendidikan terbanyak yang mengalami postpartum blues adalah SMA/SMK yaitu 22 (55\%) dari 40 responden mengalami postpartum blues dengan rincian 8 (20\%) postpartum blues ringan, $7 \quad(17,5 \%)$ postpartum blues sedang dan 7 (17,5\%) postpartum blues berat. Pendidikan merupakan upaya nyata untuk memfasilitasi individu lain, dalam mencapai kemandirian mentalnya sehingga survive di dalam kompetisi kehidupannya. Pengaruh bimbingan dan arahan dari orang dewasa kepada orang lain, untuk menuju kearah kedewasaan, kemandirian serta kematangan mentalnya. Tingkat pendidikan sangat berpengaruh terhadap kecerdasan emosional, ibu yang memiliki tingkat pendidikan tinggi akan memiliki cara berfikir yang lebih rasional, dan semakin mudah untuk menerima informasi (Desfanita, 2015).

\section{Paritas Terhadap Terjadinya Postpartum blues}

Berdasarkan hasil analisis bivariate dan multivariate menunjukkan bahwa ibu nifas yang memiliki paritas multipara lebih banyak pada ibu yang mengalami postpartum blues $(41,4 \%)$ dibandingkan dengan ibu yang memiliki paritas primipara (31,7\%). Paritas dalam hasil analisis statistik menunjukkan $p$-value sebesar 0,067 $(p>0,05)$, yang artinya paritas tidak berhubungan terhadap terjadinya postpartum blues.

Hasil penelitian ini tidak sesuai dengan hasil penelitian yang menunjukkan bahwa variabel paritas primipara didapatkan nilai $p$ sebesar 0,007 $(p<0,05)$ dengan $\mathrm{RP}=1,94$ yang berarti bahwa ibu primipara mempunyai peluang 1,94 kali untuk mengalami postpartum blues dibandingkan dengan ibu multipara. Pengalaman selama persalinan, rasa sakit yang luar biasa saat proses kelahiran bisa menjadi faktor pencetus, misalnya pada ibu yang harus di induksi beberapa kali, ketuban pecah sebelum mengalami proses pembukaan, episiotomy yang menimbulkan rasa sakit dan nyeri atau juga persalinan dengan operasi. Pengalaman dalam melahirkan memegang peranan yang penting dalam kejadian postpartum blues. Ibu yang baru melahirkan pertama kali cenderung lebih mengalami postpartum blues dibandingkan dengan ibu yang sudah pernah mengalami persalinan sebelumnya. Ibu yang baru pertama kali melahirkan akan melakukan adaptasi perubahan peran yang belum pernah dilalui sebelumnya sehingga lebih cenderung mengalami postpartum blues (Fatmawati, DA, 2015).

\section{Status Ekonomi Terhadap Terjadinya Postpartum blues}

Berdasarkan hasil analisis bivariate menunjukkan bahwa ibu nifas yang memiliki status ekonomi rendah lebih banyak pada ibu yang mengalami postpartum blues (51,3\%) dibandingkan dengan ibu yang memiliki status ekonomi tinggi $(17,4 \%)$, nilai $p$-value 0,000 yang berarti status ekonomi memiliki hubungan terhadap terjadinya postpartum blues. Sedangkan hasil multivariate menunjukkan bahwa $p$-value sebesar 0,000 ( $p$-value $<0,05)$ yang artinya status ekonomi merupakan faktor risiko terhadap terjadinya postpartum blues dan ibu nifas yang memiliki status ekonomi rendah memiliki peluang 3,559 kali untuk terjadinya postpartum blues dibandingkan dengan ibu yang memiliki status ekonomi tinggi ( $\mathrm{OR}=3,559 ; 95 \% \mathrm{Cl}$ : 1,964-6,448). 
Hasil penelitian ini sesuai dengan hasil penelitian menunjukkan terdapat hubungan yang bemakna antara pendapatan dengan kejadian postpartum blues ( $p$-value 0,009$)$. Keluarga yang memiliki pendapatan rendah mempunyai kemungkinan 4,464 kali mengalami postpartum blues. Keadaan ekonomi yang rendah dapat menimbulkan stres di keluarga yang mempengaruhi depresi ibu setelah melahirkan. Selain itu bisa berasal dari keadaan emosional, seperti konflik dalam keluarga. Bahkan kegiatan yang seharusnya mendatangkan kebahagian seperti kelahiran bayi bisa menimbulkan tekanan karena mereka menimbulkan perubahan baru dalam hidup seorang (Alifah, FN, 2016).

\section{Dukungan Sosial Suami Terhadap kejadian Postpartum blues}

Berdasarkan hasil analisis bivariate menunjukkan bahwa ibu nifas yang memiliki dukungan sosial suami kurang, lebih banyak pada ibu yang mengalami postpartum blues $(76,7 \%)$ dibandingkan dengan ibu yang memiliki dukungan sosial suami baik $(30,7 \%)$. Hasil ini sejalan dengan penelitian yang dilakukan oleh Samria dan Haerunnisa, I (2021), yang menyatakan $47,5 \%$ ibu mengalami postpartum karena tidak mendapat dukungan suami.

Hasil uji statistik menunjukkan nilai $p$-value $0,000(p<0,05)$ yang berarti dukungan sosial suami memiliki hubungan terhadap kejadian postpartum blues. Sedangkan hasil multivariate menunjukkan bahwa $p$-value sebesar $0,000(p$-value $<0,05)$ yang artinya dukungan sosial suami merupakan faktor risiko yang paling dominan terhadap terjadinya postpartum blues. Ibu nifas yang memiliki dukungan sosial suami kurang memiliki peluang 6,389 kali untuk terjadinya postpartum blues dibandingkan dengan ibu yang memiliki dukungan sosial suami baik (OR=6,389; $95 \% \mathrm{Cl}$ : 2,90514,050).

Hasil penelitian ini sejalan dengan hasil penelitian yang menunjukkan bahwa dukungan sosial suami sedang didapatkan nilai $p$ sebesar 0,000 (ppostpartum dengan dukungan sosial suami sedang mempunyai peluang 2,44 kali untuk mengalami postpartum blues dibandingkan dengan ibu postpartum dengan dukungan sosial suami yang tinggi (Fatmawati, DA, 2015). Nurhayati, NA (2021) menyatakan hal yang sama yanitu ibu yang tidak mendapat dukungan suami mempunyai peluang 77 kali lebih besar mengalami postpartum blues dibandingkan ibu yang mendapatkan dukungan suami.

Dukungan suami adalah faktor yang paling dominan yang menyebabkan terjadinya postpartum blues. Dukungan suami sangat diperlukan, karena ibu tidak akan merasa beban dengan apa yang terjadi pada dirinya, baik dukungan saat hamil, saat bersalin maupun masa nifas. Perhatian suami, komunikasi yang dijalin, sikap dan perilaku suami dalam membantu ibu baik dalam kehamilan, persalinan dan nifas akan mempengaruhi kondisi ibu (Desfanita et. al, 2015). Hal yang sama disampaikan oleh Winarni, LM (2018), bahwa dukungan suami berhubungan dengan kondisi psikologis ibu postpartum.

Kurangnya dukungan sosial keluarga atau suami akan berdampak ke keadaan psikis ibu yang tengah mengalami postpartum blues. Ketidaktahuan ibu postpartum dan keluarga tentang postpartum blues juga akan berdampak pada kondisi ibu postpartum yang mengalami gejala postpartum blues (Qiftiyah. M, 2018).

\section{Simpulan}

Simpulan dari hasil penelitian ini yaitu masih terdapat ibu nifas yang mengalami postpartum blues sebanyak 112 orang (37,3\%) di RSUD Dr. Dradjat Prawiranegara. Faktor risiko yang mempengaruhi terjadinya postpartum blues yaitu usia (OR=2,062; 95\% Cl: 1,090-3,903), status ekonomi (OR=3,559; 95\% Cl: 1,964-6,448) dan dukungan sosial suami (OR=6,389; $95 \% \mathrm{Cl}: 2,905-$ 14,050), sedangkan pendidikan dan paritas tidak terbukti secara statistik. Faktor dukungan sosial suami merupakan faktor risiko yang paling dominan berkontribusi terhadap terjadinya postpartum blues.

Dengan diketahuinya faktor risiko yang paling berkontribusi (dalam hal ini dukungan sosial suami) terhadap terjadinya postpartum blues, maka diperlukan tindakan preventif, seperti melibatkan suami dalam memberikan informasi tentang kesehatan ibu dan anak, serta antisipasi terhadap deteksi dini postpartum blues dengan kualitas penggalian informasi pasien (anamnesis), sehingga dapat menurunkan angka kejadian postpartum blues. 


\section{Ucapan terima kasih}

Peneliti mengucapkan terimakasih kepada KEMENRISTEKDIKTI yang telah mendanai penelitian ini dalam Hibah Penelitian Dosen Pemula Tahun Pendanaan 2021 dan RSUD Dr. Dradjat Prawiranegara yang telah memberikan izin untuk dilakukan penelitian ini.

\section{Daftar Pustaka}

Alifah,F.N., 2016, “Hubungan Faktor Psikososial Terhadap Kejadian Postpartum Blues di Ruang Nifas RSUD dr. Abdoer Rahem Situbondo," Universitas Airlangga Surabaya.

Cunningham, Leveno, Bloom, Hauth, Rouse, Spong, 2012. Obstetri Williams. Jakarta. EGC

Desfanita et al, 2015, "Faktor-Faktor yang Mempengaruhi Postpartum Blues," J. Progr. Stud. Ilmu Keperawatan Univ. Riau.

Fatmawati, D.A., 2015, "Faktor Risiko yang Berpengaruh Terhadap Kejadian Postpartum Blues," J. Edu Heal., vol. Vol. 5 No., no. 2087-3271, pp. 82-157.

Fitriana, L.A., \& Nurbaeti, S., 2016, Gambaran Kejadian Postpartum Blues Pada Ibu Nifas Berdasarkan Karakteristik Di Rumah Sakit Umum Tingkat IV Sariningsih Kota Bandung, Jurnal Pendidikan Keperawatan Indonesia, Vol. 2 No. 1 . pp. 44-51, DOI: https://doi.org/10.17509/jpki.v2i1.2852

Kerstin UM, Prime DK., 2013. Oxytocin effects in mothers and infants during breastfeeding. Infant, 9(6):201-6

Kirana, 2015, "Hubungan Tingkat Kecemasan Post Partum Dengan Kejadian Post Partum Blues Di Rumah Sakit Dustira Cimahi," J. IImu Keperawatan, vol. Volume III.

Nurhayati, N.A, 2021. Hubungan Dukungan Suami pada Ibu Pasca Melahirkan dengan Postpartum Blues. Syntax Idea, 3(1), pp 213221. DOI: https://doi.org/10.36418/syntaxidea.v3i1.973
Pramasatya. I., 2018, "Hubungan Antara Usia dan Paritas dengan Kejadian Baby Blues Syndrome," Universitas Muhammadiyah Surakarta.

Qiftiyah, M., 2018, "Gambaran Faktor-Faktor (Dukungan Keluarga, Pengetahuan, Status Kehamilan Dan Jenis Persalinan) Yang Melatarbelakangi Kejadian Post Partum Blues Pada Ibu Nifas Hari Ke-7 (Di Polindes Doa Ibu Gesikharjo dan Polindes Teratai Kradenan Palang)," J. Kebidanan Univ. Islam Lamongan, Vol. 10.

Rini. S., 2016. Panduan Asuhan Nifas dan Evidence Based Practise. Yogyakarta: Deepublish.

Salmah, 2018, "Manajemen Asuhan Kebidanan Postnatal Care pada Ny. R dengan Postpartum Blues 02-29 Juli 2018 di RSUD Syekh Yusuf," Makassar.

Samria dan Haerunnisa, I, 2021. Hubungan Dukungan Suami dengan Kejadian Post Partum Blues di Wilayah Perkotaan. Jurnal Kesehatan Masyarakat (J-KESMAS), 7(1) pp 52-58. DOI: http://dx.doi.org/10.35329/jkesmas.v7i1

Winarni, L.M, Winarni E, Ikhlasiah, M, 2018. Pengaruh DUkungan Suami dan Bounding Attachment dengan Kondisi Psikologis Ibu Postpartum. Jurnal IImiah Bidan, 3(2), https://ibi.or.id/journal/index.php/jib/articl e

Yodatama, et al, 2015, "Hubungan Bounding Attachment dengan Resiko Terjadinya Postpartum Blues pada Ibu Postpartum dengan Sectio Caesaria di Rumah Sakit Ibu dan Anak (RSIA) Srikandi IBI Kabupaten Jember," J. Progr. Stud. IImu Keperawatan Univ. Jember, Vol. 3. 